\title{
Apparent sediment diffusion coefficients for oxygen and oxygen consumption rates measured with microelectrodes and bell jars: applications to oxygen budgets in estuarine intertidal sediments (Oosterschelde, SW Netherlands)*
}

\author{
P. A. G. Hofman, S. A. de Jong, E. J. Wagenvoort, A. J. J. Sandee \\ Delta Institute for Hydrobiological Research, Vierstraat 28, 4401 EA Yerseke, The Netherlands
}

\begin{abstract}
Oxygen fluxes in shallow marine sediments exceeded calculated oxygen fluxes based on molecular diffusion of oxygen. Oxygen fluxes measured with bell jars in a stagnant lagoon, combined with oxygen gradients measured with microelectrodes (bell jar/microelectrode method), resulted in apparent sediment diffusion coefficients 2 to 3 times higher than the molecular coefficient. We have developed a new method to calculate the apparent sediment diffusion coefficient from oxygen gradient measurements and independently measured downward-directed oxygen production fluxes, both measured with microelectrodes (microelectrode gradient/production method). Diffusion coefficients calculated in this way differed at most $13 \%$ from the apparent sediment diffusion coefficients calculated using the bell jar/microelectrode method. The microelectrode gradient/production method was applied to emerged sediments of the Oosterschelde estuary (SW Netherlands), and apparent diffusion coefficients for these sediments exceeded molecular diffusion by 2 to 5 times. Dark oxygen gradients measured with microelectrodes were used to calculate the oxygen consumption rate of the sediment. The $Q_{10}$ value for this rate ranged from 1.3 to 2.7 . Two types of oxygen consumption rates were distinguished. A light-independent oxygen consumption rate depending on diffusion from the overlying water or air was found, varying between 0.63 to $3.65 \mathrm{mmol} \mathrm{O}_{2} \mathrm{~m}^{-2} \mathrm{~h}^{-1}$ at different stations. This consumption increased by 12 to $14 \%$ of the gross oxygen production during the emersion period in light, in the presence of benthic microalgal production. A net outflux of maximum $45 \mathrm{mmol} \mathrm{O}_{2} \mathrm{~m}^{-2}$ was found for the entire emersion period, whereas over a $24 \mathrm{~h}$ period production and consumption of oxygen were in equilibrium. Thus, mineralization and respiration processes within the sediment consume most of the oxygen produced by benthic microalgae on a daily basis.
\end{abstract}

\section{INTRODUCTION}

In recent years great progress has been made in research on oxygen transport and cycling in marine sediments, both deep-sea (Reimers et al. 1984, Reimers 1987) and intertidal (Rutgers van der Loeff et al. 1981, Baillie 1986, Andersen \& Helder 1987).

Sediment oxygen consumption can be measured indirectly in bell jars or cores as the decrease of oxygen concentration in the enclosed overlying water column (Rutgers van der Loeff et al. 1981, Van Es 1982, Grant 1986, Reimers \& Smith 1986, Andersen \& Helder 1987),

\footnotetext{
- Communication no. 508 of the Delta Institute
}

or directly in the sediment as described by Revsbech \& Jørgensen (1983). In bell jars, net oxygen fluxes are measured. There is no distinction between gross production, consumption and transport of oxygen.

The development of microelectrodes to assess dissolved oxygen in marine sediments (Revsbech et al. 1980) and the light-dark shift method for photosynthetic production measurements (Revsbech \& Jørgensen 1983) are important for studies of oxygen evolution in undisturbed sediments. Although microelectrodes precisely measure actual concentrations and thus oxygen gradients, oxygen fluxes can only be estimated, since simultaneous measurement of the sediment diffusion coefficient is not possible. Oxygen fluxes can be calcu- 
lated with Fick's first law of diffusion: $F=-D \times \delta c / \delta x$, in which $\mathrm{D}=$ the diffusion coefficient and $\delta c / \delta \mathrm{x}=$ the slope of the oxygen profile. Jørgensen \& Revsbech (1985) and Kuenen et al. (1986) calculated oxygen fluxes from the slope of the oxygen profile in the diffusive boundary layer (in the overlying water) and the molecular diffusion coefficient. The apparent sediment diffusion coefficients are often much higher than molecular diffusion due to bio-irrigation and bioturbation (Krantzberg 1985, Reimers \& Smith 1986, Andersen \& Helder 1987, Silverberg et al. 1987), evapotransport (Baillie 1986), and overlying water current velocity (Booy et al. in press). Lindeboom et al. (1985), Reimers \& Smith (1986) and Baillie (1986) combined oxygen fluxes from bell jars or incubated cores, with oxygen gradients in sediments (microelectrode technique) for apparent diffusion coefficient measurements. They found apparent sediment diffusion coefficients, for shallow-water marine environments, up to 10 times higher than the molecular diffusion coefficient.

For diffusion coefficient and oxygen consumption rate measurements on emerged sediments these methods are very inaccurate and do not match in situ conditions. In bell jars there is oxygen exchange with overlying water and not with air. Primary production rates cannot reach the values measured on emerged sediments due to light extinction (De Jong et al. unpubl.).

In this study we calculated apparent oxygen diffusion coefficients using Fick's first law of diffusion with (1) oxygen flux measurements in bell jars, combined with corresponding gradients measured with microelectrodes, and (2) downwards directed oxygen fluxes from direct microelectrode photosynthesis measurements, combined with oxygen gradients. Both methods were compared in the stagnant saline Lake Grevelingen. The second method was applied on emerged intertidal flats of the Oosterschelde estuary (SW Netherlands) to calculate sediment consumption rates. These consumption rates, combined with oxygen production measurements (De Jong et al. unpubl.), were used to calculate oxygen budgets over the emersion period and a $24 \mathrm{~h}$ period.

\section{MATERIALS AND METHODS}

Investigation area and sampling sites. Oxygen production and consumption were measured at different locations in the former estuary Lake Grevelingen (closed in 1971), and in the Oosterschelde estuary, SW Netherlands (Fig. 1). Lake Grevelingen is now a stagnant lagoon. It is $24 \mathrm{~km}$ long, 4 to $10 \mathrm{~km}$ wide and has a water surface of $108 \mathrm{~km}^{2}$ and a salinity of $30 \%$. During 17 to 22 September 1986 , sediment samples were taken at a water depth of 3 and $7 \mathrm{~m}$ (Stn 6). At $3 \mathrm{~m}$, lightlimited benthic primary production took place (De Jong et al. unpubl.), whereas at $7 \mathrm{~m}$ no benthic primary production could be detected, at light intensities less than $1 \%$ of surface irradiance. The Oosterschelde estuary is a tidal system of ca $370 \mathrm{~km}^{2}$ (45 km length and 4 to $10 \mathrm{~km}$ width). In April 1986 measurements were made at 5 stations chosen on intertidal flats (Fig 1, Stns 1 to 5). Stns 1, 2, 3 and 4 were situated along tidal channels and were more influenced by tidal dynamics than was Stn 5, located adjacent to a salt marsh. The emersion period varied between 5 and $7 \mathrm{~h}$. In general,

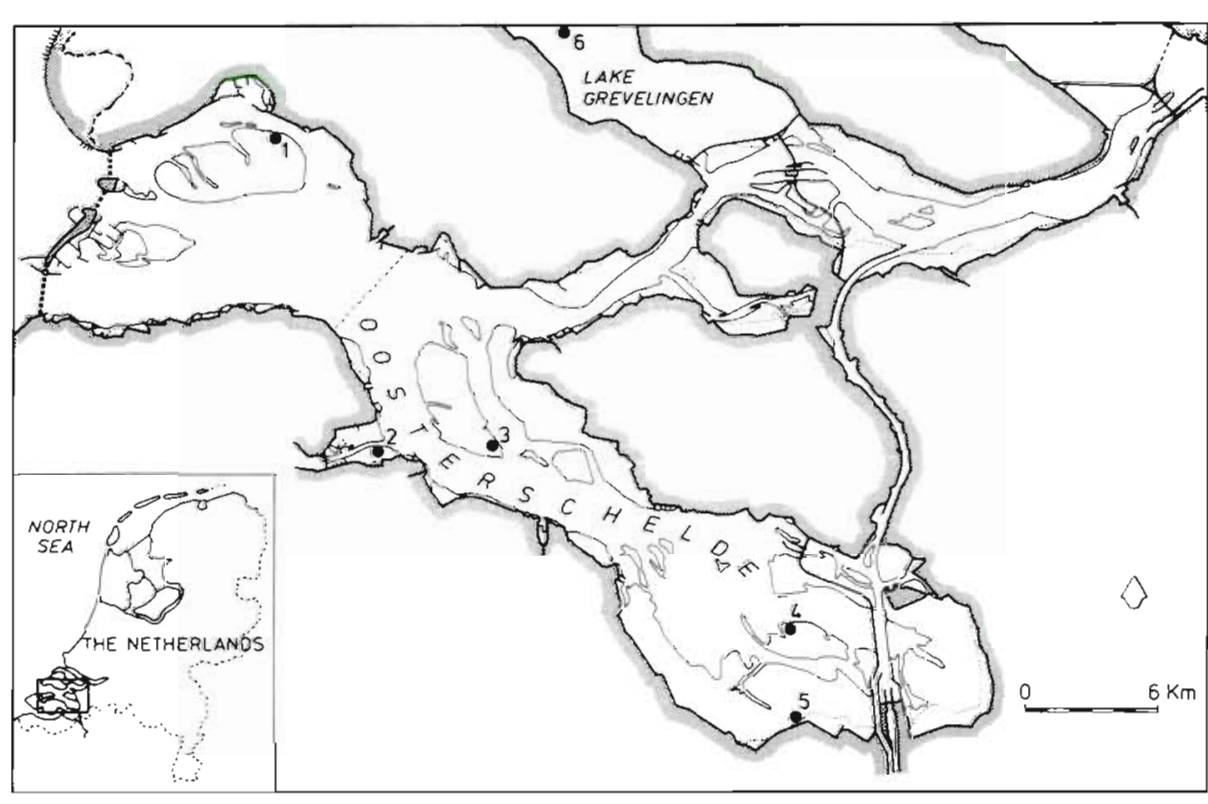

Fig. 1. Sampling stations in the Oosterschelde Estuary and Lake Grevelingen, SW Netherlands 
salinity of the interstitial water ranged from 27 to $36 \%$ during the period of emersion. Oxygen consumption rates and net oxygen production rates were measured with bell jars and oxygen microelectrodes.

Bell jar method. Bell jars were made of plexiglass cylinders (i.d. $45 \mathrm{~cm}$, height $33 \mathrm{~cm}$ ). They had a removable lid in which a YSI oxygen electrode (Model no. 5739, Yellow Springs Instr., Inc.), a thermistor and a stirring device were mounted. The cylinders were gently pushed into the sediment ( 3 to $5 \mathrm{~cm}$ deep) by SCUBA divers. The divers checked whether the sediment surface was undisturbed. If so, the lid was closed and measurement started. Oxygen and temperature were recorded continuously during 2 to $8 \mathrm{~h}$. Oxygen production was measured in clear bell jars. For consumption measurements during the light period, some bell jars were covered with black plastic sheets. The bell jar measurements were finished before oxygen concentration reached $50 \%$ saturation or $150 \%$ oversaturation in overlying water. Oxygen increase and decrease were linear. In the light no oxygen bubbles appeared in the bell jars during the measuring periods of 2 to $4 \mathrm{~h}$. The water column was stirred continuously at such a rate that oxygen gradients in the sediment, measured with microelectrodes inside and outside the bell jars, showed no significant differences. The macrooxygen electrodes were calibrated at the beginning and end of each incubation period, and oxygen concentrations of water overlying the sediment cores were measured with the Winkler method (Bryan et al. 1976). At the start of each bell jar experiment, sediment samples were taken directly outside the bell jar with plexiglass corers (i.d. $6 \mathrm{~cm}$ ), with 10 to $15 \mathrm{~cm}$ overlying water for microelectrode measurements. At the end of each experiment, sediment samples were taken outside and inside the bell jars. Then the bell jars were moved to a new site, and a new measurement started. Measurement periods lasted $36 \mathrm{~h}$, in which bell jars were moved 5 to 6 times.

For oxygen production and consumption measurements on the emerged flats of the Oosterschelde estuary, 2 cores were taken at the same time and measured immediately with microelectrodes, one under in situ light conditions and the other in the dark. A detailed description of in situ light measurements will be given in a future paper (De Jong et al. unpubl.).

Microelectrode method. Primary production and oxygen micro-gradients were measured with oxygen microelectrodes as described by Revsbech et al. (1983) and de Jong et al. (unpubl.). In the construction of microelectrodes, cellulose nitrate membranes show several advantages over DePeX as used by Revsbech \& Jørgensen (1983). The cellulose nitrate membrane is very thin and is simply made by dipping the electrode in cellulose nitrate dissolved in acetone. For measure- ments, selected microelectrodes had a $90 \%$ response time $<0.05 \mathrm{~s}$ and a tip diameter of 5 to $10 \mu \mathrm{m}$. Oxygen profiles were measured with a spatial resolution of $100 \mu \mathrm{m}$. Oxygen production by photosynthesizing benthic microalgae was measured by darkening lightexposed sediment cores for a few seconds and recording the subsequent decrease in oxygen concentration as discussed by Revsbech \& Jørgensen (1983) and Kuenen et al. (1986). Oxygen production rates were measured with a spatial resolution of $50 \mu \mathrm{m}$ (De Jong et al. unpubl.). Microelectrodes were calibrated by reading the electrode signal in the overlying water above the boundary layer. The oxygen concentration was determined by a 2- or 3-fold Winkler titration (Bryan et al. 1976). The readings in the anoxic part of the sediment were used as zero values. Electrode readings were linear with oxygen concentration.

Porosity. Porosity is defined as the volume of interconnected porewater relative to the volume of total sediment, provided that it is saturated with water (Berner 1980, Ullman \& Aller 1982). Sediment was sampled once a day (Oosterschelde intertidal sediment around low tide), and sliced in 1 or $2 \mathrm{~mm}$ layers up to $10 \mathrm{~mm}$ depth. The water content of each $2 \mathrm{~mm}$ slice was related to its porosity. This factor was used to calculate porosity for the top millimeters of the sediment from the known water content at each sampling time.

Assumptions and calculations.

Assumptions: For diffusion coefficient and oxygen consumption rate calculations the following assumptions were made:

(1) The oxygen flux into the sediment can be described by Fick's first law of diffusion:

$$
F_{\mathrm{O}_{2}}=-\Phi D_{\alpha}\left(\delta \mathrm{O}_{2} / \delta x\right)_{x=0}
$$

where $F_{\mathrm{O}_{2}}=$ flux of oxygen $\left(\mathrm{mmol} \mathrm{O}_{2} \mathrm{~m}^{-2} \mathrm{~h}^{-1}\right) ; \Phi=$ mean porosity for aerobic sediment layer; $D_{a}=$ apparent sediment diffusion coefficient $\left(\mathrm{m}^{2} \mathrm{~h}^{-1}\right)$; and $\delta \mathrm{O}_{2} / \delta x$ $=$ oxygen concentration gradient over depth interval $x$ (mmol $\mathrm{O}_{2} \mathrm{~m}^{-4}$ )

(2) The apparent sediment diffusion coefficient is constant over the oxic sediment layer.

Calculation of the apparent sediment diffusion coefficient: (A) Bell jar/microelectrode method (Lindeboom et al. 1985, Baillie 1986). The net oxygen flux ( $\left.F_{\mathrm{O}_{2} \text { bell jar }}\right)$ across the sediment-water interface is calculated from the rate of change in oxygen concentration in the water inside the bell jar. The oxygen gradient $\left(\delta \mathrm{O}_{2} / \delta x\right)$ in the sediment is measured with microelectrodes (Fig. 2). The diffusion coefficient is calculated from:

$$
D_{\mathrm{a}}=-F_{\mathrm{O}_{2}} \text { bell jar } /\left(\Phi \delta \mathrm{O}_{2} / \delta \mathrm{x}\right) \text {. }
$$

Apparent sediment diffusion coefficients, measured during a dark period with downward oxygen fluxes 


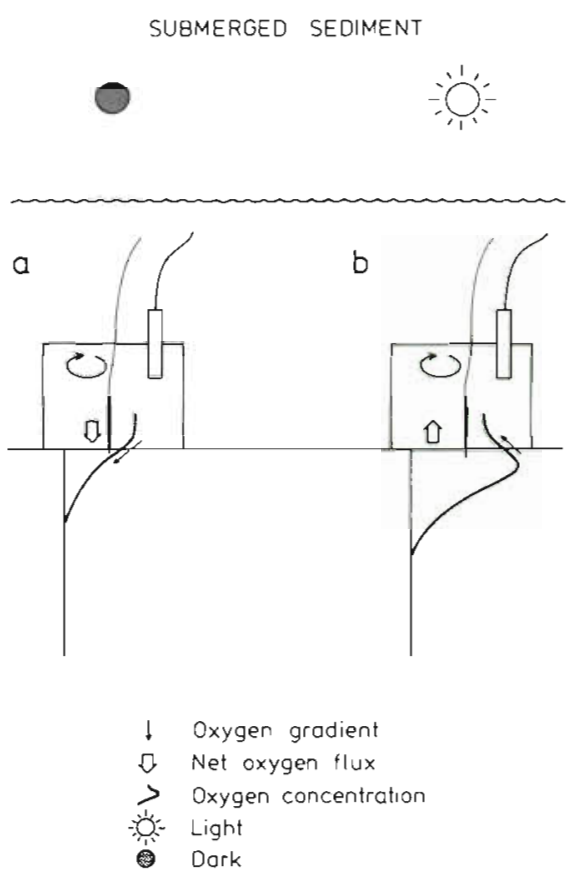

Fig. 2. Scheme of bell jar/microelectrode method according to Lindeboom et al. (1985). (a) Downward oxygen flux (mmol $\mathrm{m}^{-2} \mathrm{~h}^{-1}$ ) measured with bell jar, and downward-directed oxygen gradient ( $\mathrm{mmol} \mathrm{m} \mathrm{m}^{-4}$ ) measured with microelectrode in the dark. (b) Upward flux and upward-directed gradient in the light

(Fig. 2a) or during a light period with upward oxygen fluxes (Fig. 2b), are of the same order of magnitude.

(B) Microelectrode oxygen gradient/production method. Oxygen production, oxygen consumption and diffusion of oxygen over depth interval $x_{0}-x_{1}$ result in an upward-directed oxygen gradient $\left(\delta \mathrm{O}_{2} / \delta x_{\text {up }}\right)$ and an upward-directed flux $\left(F_{\mathrm{O}_{2}}\right.$ upi Fig. 3a). Oxygen production at depth interval $x_{1}-x_{2}$, oxygen consumption, and diffusion of oxygen over depth interval $x_{1}-x_{3}$ together result in a downward-directed oxygen gradient $\left(\mathrm{\delta O}_{2}\right)$ $\left.\delta x_{\text {down }}\right)$. We assumed that the integrated independently determined oxygen production at depth interval $x_{1}-x_{2}$ $\left(F_{O_{2}}\right.$ down $)$ was the source of oxygen over interval $x_{1}-x_{3}$.

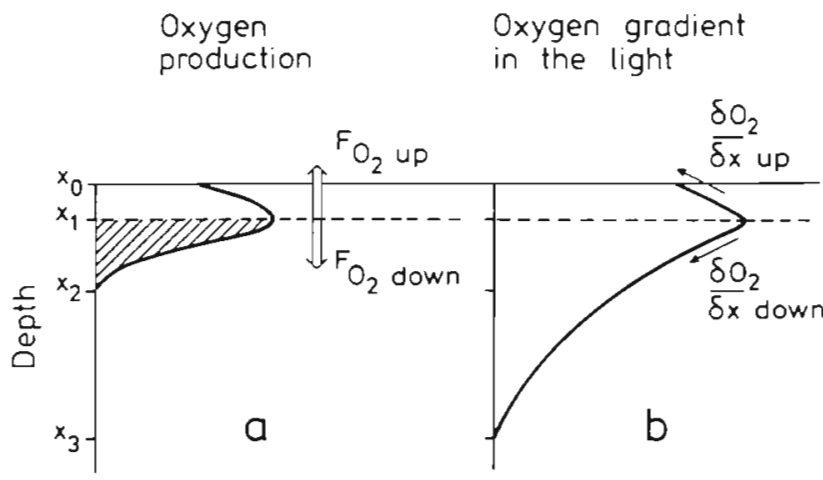

The apparent diffusion coefficient can be calculated from:

$$
D_{a}=-F_{\mathrm{O}_{2} \text { down }} /\left(\Phi \delta \mathrm{O}_{2} / \delta x_{\text {down }}\right) .
$$

Oxygen consumption rates on emerged flats can now be calculated from the dark profiles (Fig. 3c) by combining the value of $D_{a}$, calculated according to Eq. (3), with the $\mathrm{O}_{2}$ gradient measured in the dark. For this last calculation $\delta \mathrm{O}_{2} / \delta x_{\text {dark }}$ should be constant in time.

\section{RESULTS}

\section{Apparent sediment diffusion coefficients in submerged sediments}

\section{Bell jar/microelectrode method}

At Stn 6 in Lake Grevelingen, we measured oxygen fluxes with bell jars and oxygen gradients with microelectrodes. Porosity was $0.60 \pm 0.03$ at Site $1,-7 \mathrm{~m}$ $(\mathrm{n}=8)$; and $0.68 \pm 0.06$ at Site $2,-3 \mathrm{~m}(\mathrm{n}=32)$. Net oxygen fluxes measured in bell jars, microelectrodedetermined oxygen gradients and mean porosity of the upper $2 \mathrm{~mm}$ of the sediment were substituted in Fick's first law of diffusion (Eq. 2), to obtain apparent sediment diffusion coefficients. At the site with a depth of $7 \mathrm{~m}$ a mean apparent sediment diffusion coefficient of $12.0 \times 10^{-6} \mathrm{~m}^{2} \mathrm{~h}^{-1}$ (i.e. $\left.3.3 \times 10^{-5} \mathrm{~cm}^{2} \mathrm{~s}^{-1}\right)\left(\sigma_{\mathrm{n}-1}=\right.$ $1.0 \times 10^{-6}, \mathrm{n}=11 ; 16,17,18$ September 1986) was found; and at the site with a depth of $3 \mathrm{~m}$ a coefficient of $11.8 \times 10^{-6} \mathrm{~m}^{2} \mathrm{~h}^{-1}\left(\sigma_{\mathrm{n}-1}=0.8 \times 10^{-6}, \mathrm{n}=6 ; 17,18\right.$, 19, 22 September 1986) was found (Table 1).

\section{Microelectrode oxygen gradient/production method}

Gross oxygen production and oxygen gradients in the light were measured simultaneously at Stn 6 (Lake Grevelingen, $-3 \mathrm{~m}$ ) with microelectrodes. Downwarddirected oxygen fluxes, calculated from the production. measurements, and corresponding oxygen gradients

\section{Oxygen gradient \\ in the dark}

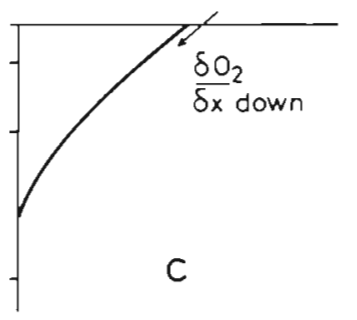

Fig. 3. Scheme of microelectrode oxygen gradient/production method. (a) Oxygen production $\left(\mathrm{mM} \mathrm{h}^{-1}\right)$ measured with microelectrode, and oxygen fluxes ( $\left.\mathrm{mmol} \mathrm{m} \mathrm{m}^{-2} \mathrm{~h}^{-1}\right)$. (b) Oxygen gradient $\left(\mathrm{mmol} \mathrm{m}^{-4}\right)$ measured with microelectrode in the light. (c) Oxygen gradient measured in the dark 
Table 1. Apparent sediment diffusion coefficients $\left(\times 10^{-6} \mathrm{~m}^{2} \mathrm{~h}^{-1}\right)$, porosity, and production-consumption relation (production: $P_{\text {grossi }}$ Consumption: $\left.R_{\mathrm{i}}, \mathrm{mmol} \mathrm{m} \mathrm{m}^{-2} \mathrm{~h}^{-1}\right)$ for Oosterschelde Stns 1 to 5 and Grevelingen Stns $6 \mathrm{a}(-3 \mathrm{~m})$ and $6 \mathrm{~b}(-7 \mathrm{~m})$

\begin{tabular}{|c|c|c|c|}
\hline Stn & $\begin{array}{c}\text { Apparent sediment diffusion } \\
\text { coefficient (n) }\end{array}$ & Porosity (n) & Production-consumption relation \\
\hline 1 & $25.7 \pm 5.1^{\mathrm{a}}(9)$ & $0.54 \pm 0.03(7)$ & $R_{1}=1.31+0.13 P_{\text {gross }}$ \\
\hline 2 & $37.3 \pm 8.0^{\text {a }}(9)$ & $0.63 \pm 0.09(6)$ & $\mathrm{R}_{\mathrm{t}}=3.65+0.14 \mathrm{P}_{\text {gross }}$ \\
\hline 3 & $14.2 \pm 1.7^{a}(5)$ & $0.43 \pm 0.03(6)$ & $\mathrm{R}_{i}=0.94+0.12 \mathrm{P}_{\text {gross }}$ \\
\hline 4 & $12.8 \pm 3.0^{\mathrm{a}}(2)$ & $0.44 \pm 0.01(4)$ & $\mathrm{R}_{1}=0.63+0.12 \mathrm{P}_{\text {gross }}$ \\
\hline 5 & $31.2 \pm 5.0^{\mathrm{a}}(8)$ & $0.52 \pm 0.03(7)$ & $\mathrm{R}_{1}=3.00+0.12 \mathrm{P}_{\text {gross }}$ \\
\hline $6 a$ & $10.3 \pm 1.5^{\mathrm{a}}(10)$ & $0.68 \pm 0.06(32)$ & $\mathrm{R}_{1}=1.16+0.13 \mathrm{P}_{\mathrm{gross}}$ \\
\hline $6 a$ & $11.8 \pm 0.8^{\mathrm{b}}(6)$ & & \\
\hline $6 b$ & $12.0 \pm 1.0^{\mathrm{b}}(11)$ & $0.60 \pm 0.03(8)$ & \\
\hline
\end{tabular}

were substituted in Eq. (3), and apparent sediment diffusion coefficients were calculated. We found an apparent diffusion coefficient of $10.3 \times 10^{-6} \mathrm{~m}^{2} \mathrm{~h}^{-1}$ $\left(\sigma_{n-1}=1.5 \times 10^{-6}, \mathrm{n}=10 ; 22\right.$ September 1986). This value differs less than $13 \%$ from the sediment diffusion coefficient found with the bell jar/microelectrode method.

In a core sampled at a depth of $3 \mathrm{~m}$ in Lake Grevelingen, oxygen gradients and gross oxygen production rates were measured at different light intensities, at time intervals of $10 \mathrm{~min}$ (Fig. 4). In this figure the oxygen gradient $\left(\delta \mathrm{O}_{2} / \delta x_{\text {down }}\right)$, the corresponding gross oxygen production and thus the downward-directed oxygen flux $\left(F_{\mathrm{O}_{2} \text { down }}\right)$ increased with increasing surface irradiance. The calculated apparent sediment diffusion coefficients were $10.8,10.5$ and $10.8 \times 10^{-6} \mathrm{~m}^{2} \mathrm{~h}^{-1}$ at surface irradiances of respectively 83,172 and $310 \mu \mathrm{E}$ $\mathrm{m}^{-2} \mathrm{~s}^{-1}$. Thus, increasing downward-directed oxygen fluxes resulted in a corresponding increase in oxygen gradients, but $D_{a}$ remained constant.

We assumed the downward-directed oxygen production in interval $x_{1}-x_{2}$ to be an oxygen flux through interface $x_{1}$ (Fig. 3a). The influence of the known interval thickness $\left(x_{1}-x_{2}\right)$, which differs from the assumed zero thickness, on the calculation of $D_{a}$ was checked. We calculated the ratio of $x_{1}-x_{2}$ (thickness of oxygen production interval) to $x_{1}-x_{3}$ (oxygen penetration) depth), and compared the apparent sediment diffusion coefficients with this ratio. At stations with a large number of measurements, no significant correlation
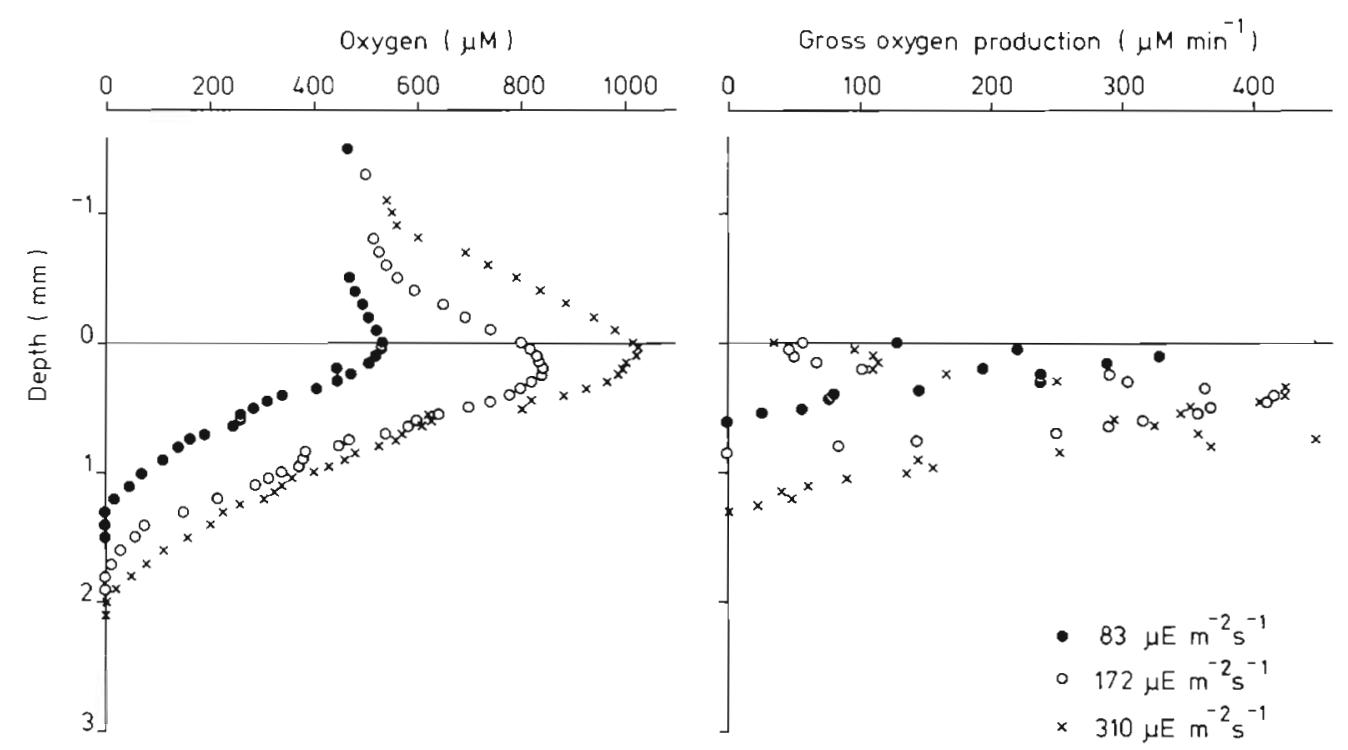

Fig. 4. Oxygen gradients and gross oxygen production measured with microelectrodes in Lake Grevelingen sediment at different sediment surface irradiances. Measurements were taken at time intervals of $10 \mathrm{~min}$ 
was found at the $5 \%$ level $(r=0.25, n=16$; $r=0.46$, $\mathrm{n}=11$ ). Thus, $D_{a}$ does not depend on the ratio of oxygen production interval to oxygen penetration depth. We conclude that the thickness of the production interval $x_{1}-x_{2}$ has no effect on the calculation of $D_{a}$.

\section{Apparent sediment diffusion coefficients in emerged sediments}

The microelectrode oxygen gradient/production method for calculating apparent sediment diffusion coefficients was used on the intertidal flats of the Oosterschelde estuary during the emersion period. Dark oxygen gradients and the apparent diffusion coefficients obtained were used to calculate oxygen consumption rate of the sediment (Table 1). The calculated apparent sediment diffusion coefficients varied from $12.8 \times 10^{-6} \mathrm{~m}^{2} \mathrm{~h}^{-1}$ (i.e. $3.6 \times 10^{-5} \mathrm{~cm}^{2} \mathrm{~s}^{-1}$ ) at Stn 4 to $37.3 \times 10^{-6} \mathrm{~m}^{2} \mathrm{~h}^{-1}$ (i.e. $10.4 \times 10^{-5} \mathrm{~cm}^{2} \mathrm{~s}^{-1}$ ) at Stn 2 (April 1986).

\section{Oxygen consumption and production}

\section{Net oxygen fluxes and gross oxygen production} in submerged sediments

Measurements of surface irradiance, gross photosynthesis (microelectrodes) and net oxygen fluxes (bell jars) over an $11 \mathrm{~h}$ period (22 September 1986) in Lake Grevelingen are shown in Fig. 5. Surface irradiance reached maximum values of $200 \mu \mathrm{E} \mathrm{m} \mathrm{m}^{-2} \mathrm{~s}^{-1}$ between 13:00 and 14:15 h (Fig. 5a). In the underwater sediments of Lake Grevelingen, photosynthesis remained light-limited. Microalgal biomass was measured, and apparent microalgal photosynthetic efficiencies were calculated from incubations (De Jong et al. unpubl.). Hence, microalgal gross oxygen production rate could be calculated at each light intensity (Fig. 5b). Six time intervals were distinguished in which the net oxygen flux measured in the bell jar remained fairly constant (Fig. 5c). Similar periods were detected in the pattern of daily surface irradiance. Net oxygen fluxes measured with the bell jars were negative at very low light intensities at the beginning and end of the light period (minimum value of $-0.8 \mathrm{mmol} \mathrm{O}_{2} \mathrm{~m}^{-2} \mathrm{~h}^{-1}$ ). Net oxygen flux increased up to $3.3 \mathrm{mmol} \mathrm{O}_{2} \mathrm{~m}^{-2} \mathrm{~h}^{-1}$ at the highest light intensities. For each time interval the mean net oxygen flux was also calculated from the microelectrode measurements (gross oxygen production - oxygen consumption). These fluxes corresponded with the bell jar fluxes, although values were less pronounced and varied between -0.7 and 2.2 mmol $\mathrm{O}_{2} \mathrm{~m}^{-2} \mathrm{~h}^{-1}$.
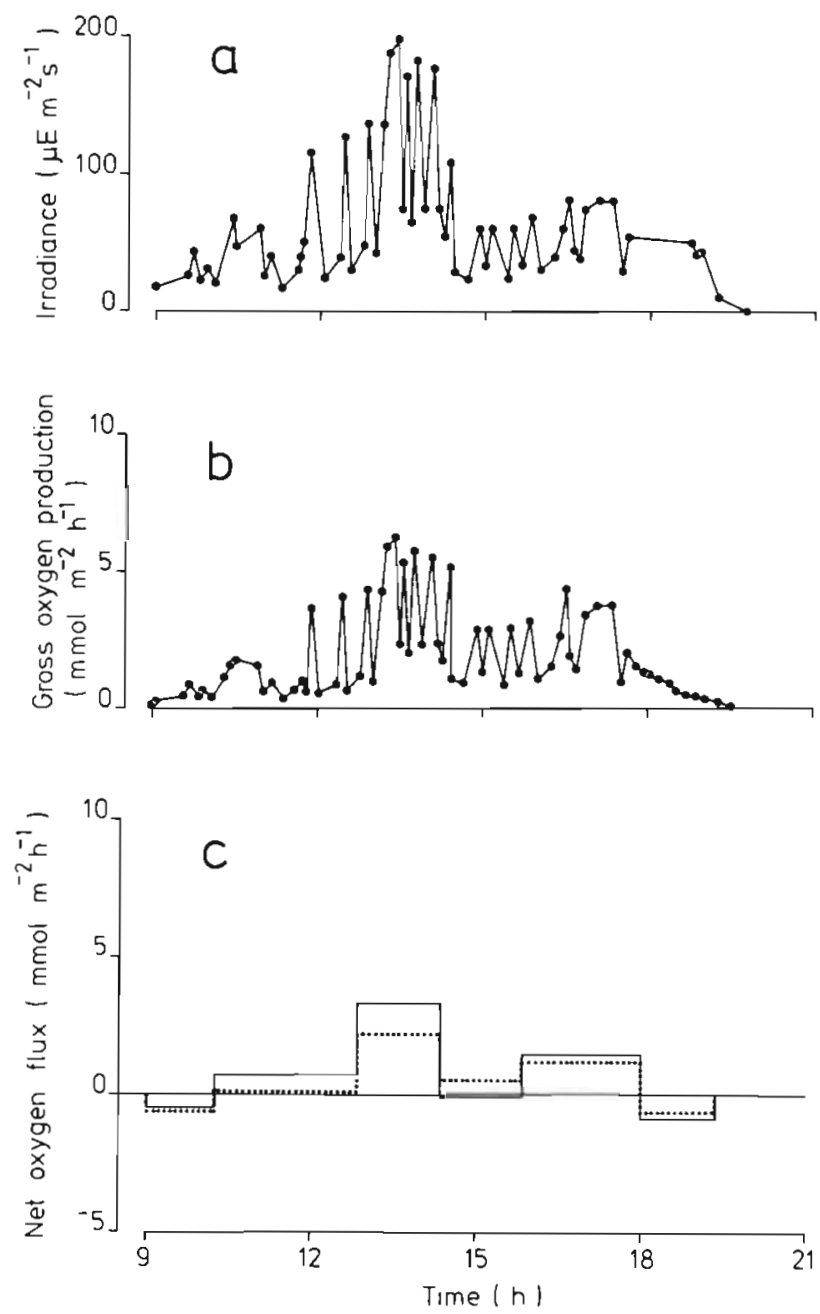

Fig. 5. (a) Irradiance, (b) gross oxygen production calculated from microelectrode measurements, and (c) net oxygen flux as measured with bell jars (-) and microelectrodes (…) during a light period in Lake Grevelingen (22 Sep 1986) at a depth of $3 \mathrm{~m}$

Net oxygen fluxes and gross oxygen production in emerged sediments

Gross oxygen production and total oxygen consumption rates were measured with microelectrodes during the light period on the emerged flats of the Oosterschelde estuary. The results from Stn 6 (Lake Grevelingen) and Stns 1 and 5 (Oosterschelde) are presented in Fig. 6. At the Grevelingen station (22 September 1986) oxygen production started at a light intensity of about $10 \mu \mathrm{E} \mathrm{m}^{-2} \mathrm{~s}^{-1}$ and increased up to 4.4 $\mathrm{mmol} \mathrm{O} \mathrm{m}^{-2} \mathrm{~h}^{-1}$ at $200 \mu \mathrm{Em}^{-2} \mathrm{~s}^{-1}$ (Fig. 6a). During the dark period we calculated a constant oxygen consumption of $1.2 \mathrm{mmol} \mathrm{O}_{2} \mathrm{~m}^{-2} \mathrm{~h}^{-1}$, using a constant apparent oxygen diffusion coefficient of $10.3 \times 10^{-6} \mathrm{~m}^{2} \mathrm{~h}^{-1}$. During the light period, oxygen consumption rates 


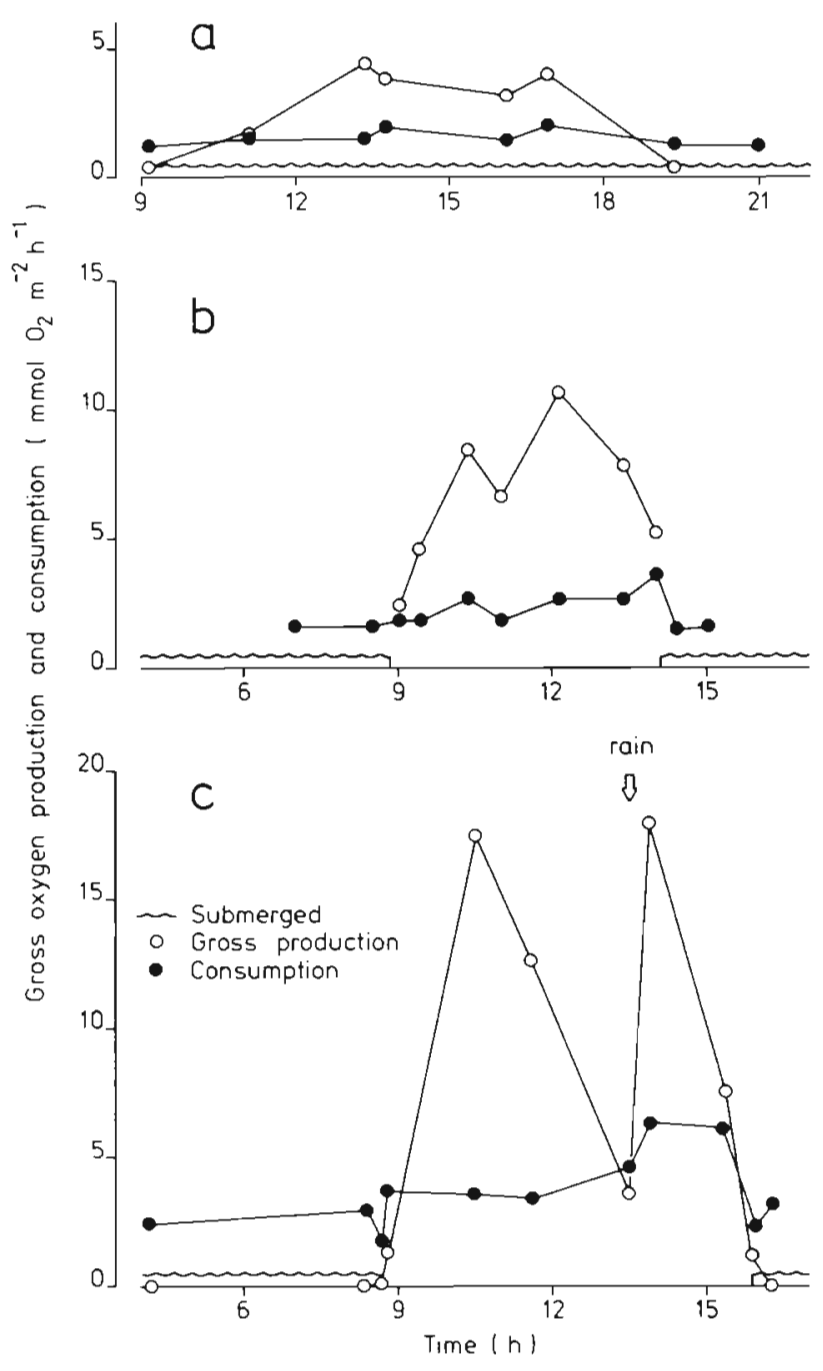

Fig. 6. Gross oxygen production and oxygen consumption measured with microelectrodes during a light period at 3 different stations. (a) Stn 6, in Lake Grevelingen (22 Sep 1986); (b) Stn 1 and (c) Stn 5, both in the Oosterschelde estuary (25 and 10 Apr 1986 respectively)

showed similar fluctuations to those of gross oxygen production rates, reaching maximum values of 2.0 mmol $\mathrm{O}_{2} \mathrm{~m}^{-2} \mathrm{~h}^{-1}$ (Fig. 6a).

Benthic microalgal photosynthesis was limited to the period of emersion on the intertidal flats of the Oosterschelde estuary. Gross oxygen production started immediately after the onset of emersion and reached maximum values of $10.6 \mathrm{mmol} \mathrm{O}_{2} \mathrm{~m}^{-2} \mathrm{~h}^{-1}$ at Stn 1 (25 April 1986; Fig. 6b) and $18.0 \mathrm{mmol} \mathrm{O} \mathrm{m}^{-2} \mathrm{~h}^{-1}$ at Stn 5 (10 April 1986; Fig. 6c) (De Jong et al. unpubl.). At Stns 3 and 5 a steep decrease in production was seen due to rainfall. During submersion we found a constant oxygen consumption rate of $1.5 \mathrm{mmol} \mathrm{O}_{2} \mathrm{~m}^{-2} \mathrm{~h}^{-1}$ at Sth 1 and $2.8 \mathrm{mmol} \mathrm{O}_{2} \mathrm{~m}^{-2} \mathrm{~h}^{-1}$ at $\mathrm{Stn} 5$. At the onset of emersion and the onset of submersion oxygen consumption rates showed a temporary decrease to 1.7 and
$2.2 \mathrm{mmol} \mathrm{O}_{2} \mathrm{~m}^{-2} \mathrm{~h}^{-1}$ respectively. During the emersion period oxygen consumption increased to 3.6 and 6.3 mmol $\mathrm{O}_{2} \mathrm{~m}^{-2} \mathrm{~h}^{-1}$ respectively and followed the pattern of gross oxygen production (Fig. 6b,c).

\section{Oxygen consumption in relation to gross oxygen production and physico-chemical parameters}

Relations between total oxygen consumption rate and temperature, maximum oxygen saturation and gross oxygen production rate were calculated. Results of linear regression (consumption vs maximum oxygen saturation) and geometric mean regression (consumption vs production) are shown in Fig. 7. The $Q_{10}$ values of oxygen consumption rates were 1.3 (at Lake Grevelingen), 1.5 (Oosterschelde Stn 1) and 2.7 (Oosterschelde Stn 5). Good correlations were found between maximum oxygen saturation and oxygen consumption ( $\mathrm{r}=0.92,0.85,0.65$, and $\mathrm{n}=10,7,10$, respectively) The correlation coefficients for gross oxygen production vs oxygen consumption rates were $0.66,0.85$ and 0.59 for Stns 6, 1 and 5 respectively $(n=11,6,9)$. In Table 1 the consumption-production relations are given for the Oosterschelde intertidal flat stations. An oxygen consumption rate depending on diffusion alone and independent of the gross oxygen production rate was found, ranging from 0.63 to $3.65 \mathrm{mmol} \mathrm{O}_{2} \mathrm{~m}^{-2} \mathrm{~h}^{-1}$. During the light period an additional oxygen consumption rate of 12 to $14 \%$ of gross oxygen production rates was found.

Gross oxygen production and consumption measurements performed in April 1986 were used to calculate an oxygen budget for all Oosterschelde stations over the emersion period and a day period (Fig. 8). Stn 2 showed the highest values. The integrated gross oxygen production over the emersion period was 75.8 mmol $\mathrm{O}_{2} \mathrm{~m}^{-2}$, and the oxygen consumption in the light was $30.6 \mathrm{mmol} \mathrm{O}_{2} \mathrm{~m}^{-2}$, resulting in a net oxygen outflux during the emersion period of $45.1 \mathrm{mmol} \mathrm{O}_{2}$ $\mathrm{m}^{-2}$. Over $24 \mathrm{~h}$, a total oxygen consumption of 98.2 $\mathrm{mmol} \mathrm{O}_{2} \mathrm{~m}^{-2}$ and a net oxygen influx of $22.4 \mathrm{mmol} \mathrm{O}_{2}$ $\mathrm{m}^{-2}$ were calculated.

Both during the night and during submersion the flux of oxygen was downward into the sediment. Net oxygen outflux, from the sediment to the atmosphere, occurred only during the emersion period.

\section{DISCUSSION}

\section{Sampling errors}

For the micro-gradient measurements with microelectrodes, sediment cores were taken by hand. Under- 

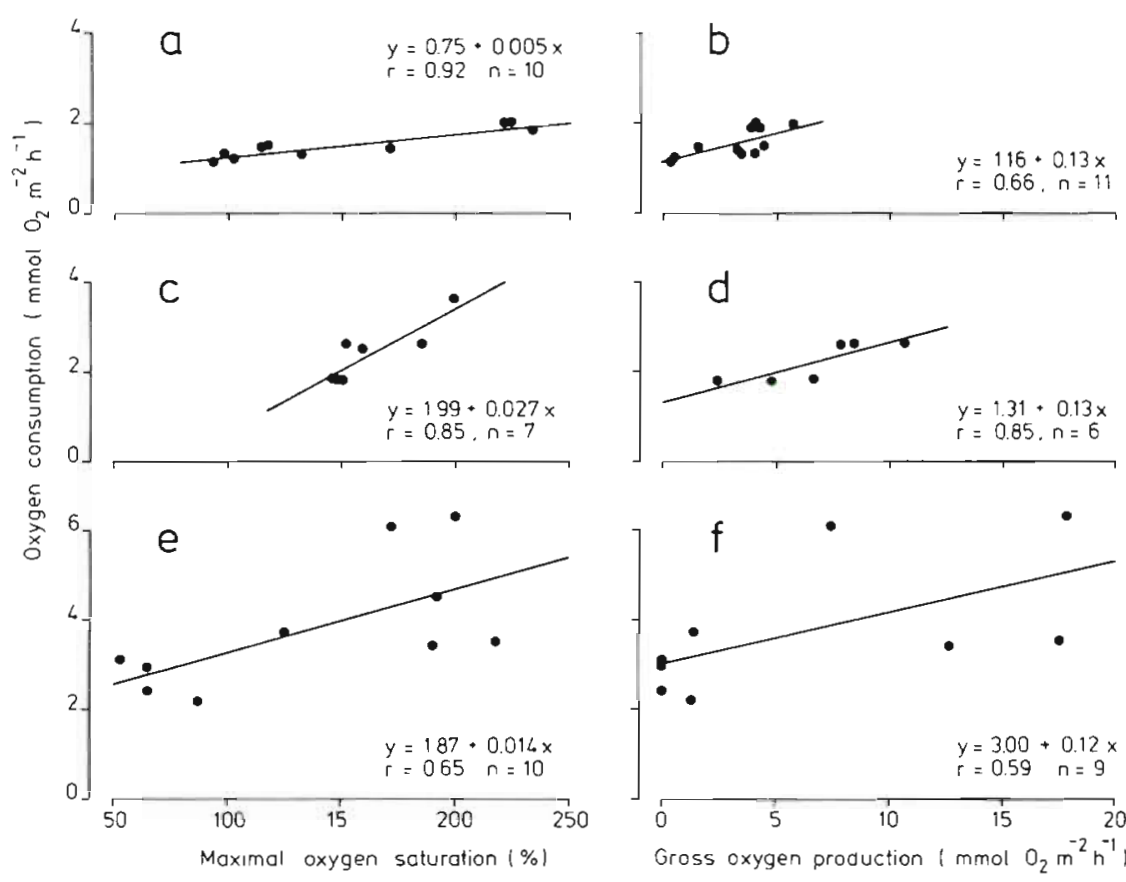

Fig. 7 Oxygen consumption in relation to maximal oxygen saturation and gross oxygen production. (a \& b) Lake Grevelingen station (17-22 Sep 1986). (c \& d) Oosterschelde Sin 1 (25 Apr 1986). (e \& f) Oosterschelde Stn 5 (9,10 Apr 1986)

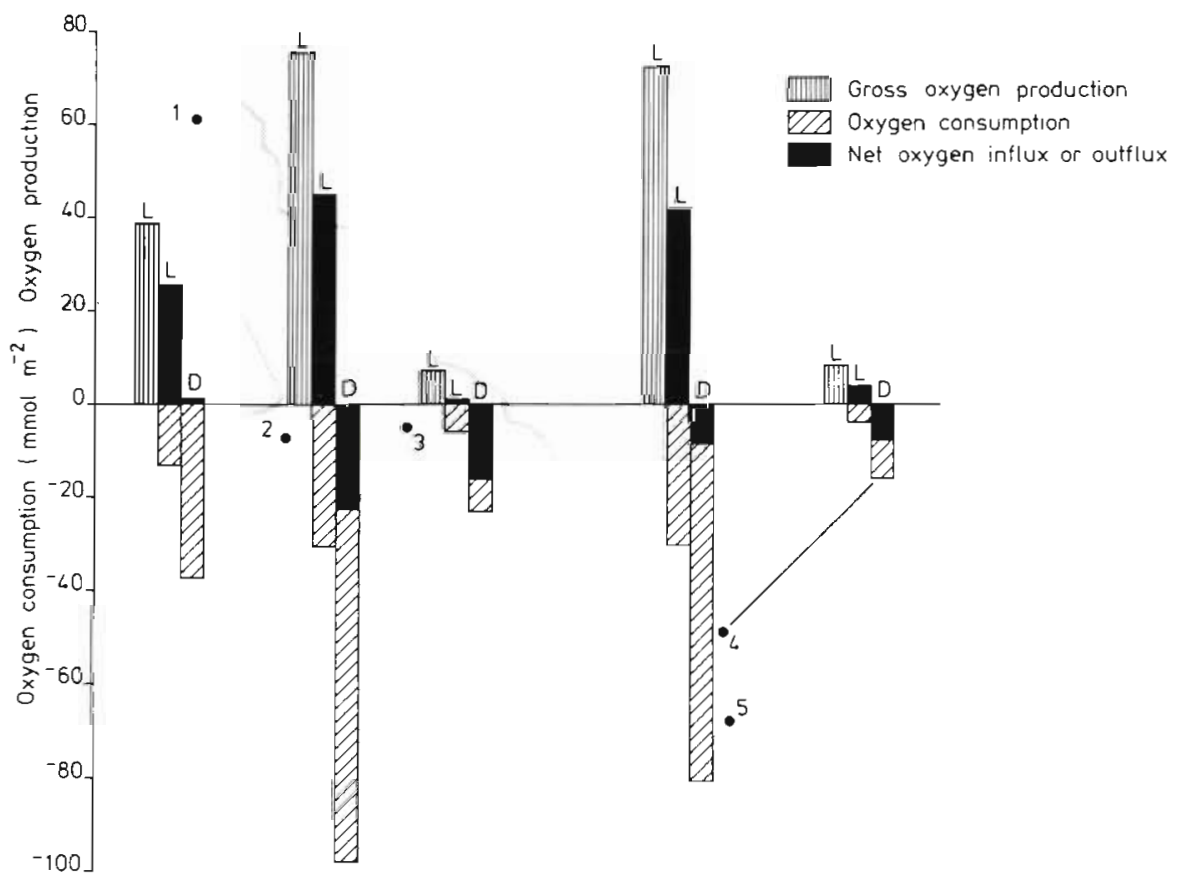

Fig. 8. Gross oxygen production, total oxygen consumption and net oxygen outflux or influx at 5 intertidal flats in the Oosterschelde Estuary (April 1986), calculated over the light period (L) and over $24 \mathrm{~h}$ (D). Stn 1:25 Apr, calculated with 7 measurements (L) and 11 measurements (D); Stn 2: 28 Apr, 6 and 8 measurements respectively; $\operatorname{Stn}$ 3: $24 \mathrm{Apr}, 4$ and 6 measurements; $\operatorname{Stn} 4: 23$ Apr, 5 and 7 measurements; Stn 5: 9, 10 Apr, 9 and 13 measurements

water sediments can easily be suspended; thus, sampling has to be done very carefully. Silverberg et al (1987) concluded from box-core experiments that little change in the oxygen gradient occurred during core retrieval. On the other hand, Reimers (1987) found discrepancies between microelectrode measurements in situ and those in box-cored deep-sea sediments; she found that oxygen concentrations in the sediment surface measured in cores were up to twice as high as in situ values. Our cores were measured within 15 min after careful sampling, and the oxygen concentrations in the overlying water did not change during repeated measurements. The slopes of the oxygen gradients remained constant for at least $10 \mathrm{~min}$. Hence, apparent sediment oxygen diffusion coefficients and oxygen fluxes are not likely to be changed by sampling and measuring and therefore are assumed to be equal to in situ values. 


\section{Determination of apparent sediment oxygen diffusion coefficients}

Bell jar/microelectrode method

For dark oxygen flux measurements in bell jars it is important that oxygen consumption remains constant during the measurement. In our experiments, oxygen could reach concentrations as low as $60 \mu \mathrm{M}$ before the oxygen consumption rate started to decline. A constant oxygen uptake rate was maintained for several hours in undisturbed sediment cores where aerobic respiration predominated (Pamatmat 1971). A nearly constant $\mathrm{O}_{2}$ consumption down to concentrations of $100 \mu \mathrm{M}$ was found by Hopkinson (1985) and Anderson et al. (1986). Our bell jar experiments were stopped at half saturation values (ca $150 \mu \mathrm{M} \mathrm{O}_{2}$ ); hence, oxygen depletion was not likely to occur.

Stirring of bell jars often does not simulate in situ water currents (Hopkinson 1985). The flow velocity of the overlying water influences the oxygen consumption rate of the enclosed sediment (Bointon et al. 1981, Booy et al. in press). The benthic boundary layer thickness and consequently diffusion through this layer depend on flow velocity (Liss 1973, Broecker \& Peng 1974, Jørgensen \& Revsbech 1985). Stirring also increases the penetration depth of the oxygen (Revsbech el al. 1980, Booy et al. in press). Thus, flow velocities due to stirring in experimental setups have to be checked with in situ values. Therefore we chose a stirring velocity at which oxygen gradients measured in sediment inside and outside the bell jars had comparable slopes and depths. Hence, the apparent sediment diffusion coefficient calculations using Fick's first law, from oxygen flux measurements combined with oxygen gradients (bell jar/ microelectrode method), will be close to in situ values.

\section{Microelectrode oxygen gradient/production method}

No correlation was found between the thickness of the oxygen production layer, responsible for downward-directed oxygen flux, and the calculated apparent sediment diffusion coefficient (the $20 \%$ variation in $D_{a}$ must be the effect of other factors such as spatial variation). Different light intensities had no effect on $D_{a}$. Thus, considering this layer as an interface should be a fair approach for the determination of the apparent sediment diffusion coefficient.

The apparent sediment diffusion coefficients calculated from the downward-directed oxygen production flux and corresponding oxygen gradients (microelectrode oxygen gradient/production method) showed a difference of $13 \%$ compared to the bell jar measurements. This difference could be an effect of infaunal activity, which does affect the net oxygen flux meas- urements made in bell jars, but it is not included in the downward-directed production fluxes measured with microelectrodes. Oxygen gradients can be seriously disturbed by macrofauna (Meyers et al. 1987). Only smoothed, undisturbed oxygen gradients were used for our calculations, thereby excluding the effects of macrozoobenthos. Meiofaunal oxygen consumption is included in the microelectrode measurements.

Our calculated apparent sediment diffusion coefficients $\left(D_{a}\right)$ for Grevelingen sediment exceed the molecular oxygen diffusion coefficient (Broecker \& Peng 1974) by a factor of 2 . These coefficients are comparable to those found by Lindeboom et al. (1985), measured at Lake Grevelingen at a depth of $1.8 \mathrm{~m}$, being $17.1 \times 10^{-6}$ $\mathrm{m}^{2} \mathrm{~h}^{-1}$ (calculated as mean sediment diffusion coefficient and corrected for porosity, $\phi \leq 0.7$, according to Ullman \& Aller 1982). Revsbech et al. (1980) found apparent diffusion coefficients ranging between $10.4 \times 10^{-6}$ and $24.5 \times 10^{-6} \mathrm{~m}^{2} \mathrm{~h}^{-1}$ for subtidal sandy sediments.

Increasing diffusion coefficients result in increasing nutrient fluxes. Silicate fluxes, for example, were found to exceed molecular diffusion by 2.2 to 6.1 times in intertidal sediments (Helder \& Andersen 1987) and 2 to 10 times in sediments at a depth of 6 to $22 \mathrm{~m}$ (Rutgers van der Loeff et al. 1987), both in the presence of macrobenthos. Deep-sea sediment research resulted in oxygen diffusion coefficients near molecular diffusion $\left(D_{0}\right), D_{0}=4.5 \times 10^{-6} \mathrm{~m}^{2} \mathrm{~h}^{-1}$ (Reimers \& Smith 1986). On intertidal flats apparent oxygen diffusion coefficients 1.4 to 3.2 times higher than molecular diffusion $\left(D_{0}=\right.$ $7.2 \times 10^{-6} \mathrm{~m}^{2} \mathrm{~h}^{-1}$ ) were found by Anderson \& Helder (1987). Baillie (1986) calculated apparent oxygen diffusion coefficients ranging from 10.7 to $135.8 \times 10^{-6} \mathrm{~m}^{2}$ $\mathrm{h}^{-1}$. In the latter 2 studies apparent oxygen diffusion coefficients were calculated from gradients and fluxes measured in cores with an overlying water column. Baillie (1986) immersed her cores taken from exposed sediment, before measuring oxygen microprofiles.

The apparent sediment diffusion coefficients calculated with the microelectrode oxygen gradient/production method in exposed cores under in situ conditions fall within in the same range: 12.8 to $37.3 \times 10^{-6} \mathrm{~m}^{2}$ $\mathrm{h}^{-1}$. However, they are not influenced by manipulation with overlying water, and approach actual values better. The apparent sediment oxygen diffusion coefficient is enhanced by the activity of the micro-, meio- and macroinfauna. Their activity results in water currents in the sediment.

\section{Net oxygen fluxes}

The microelectrode production and consumption measurements were compared with bell jar experiments in Lake Grevelingen (Fig. 5c). Apparent oxygen 
diffusion coefficients measured with both techniques were similar, apart from the effect of macrofaunal activity, which increased the influx of oxygen to the sediment in the bell jar and thus the calculated apparent sediment diffusion coefficient.

Net oxygen fluxes measured within the bell jars and with microelectrodes (gross production corrected for oxygen consumption in the light) showed some differences but the same trend (Fig. 5c). These differences can be explained by phytoplankton production in the overlying water at increasing or high light intensities or by respiration at decreasing or low light intensities. The bell jar measurements were not corrected for this phenomenon. Results of oxygen production measurements in the bell jars are very similar to the observations of Lindeboom et al. (1985).

In Lake Grevelingen sediment oxygen production, and hence production-enhanced oxygen consumption rates, occurred during the entire light period (Fig. 6a). On the Oosterschelde intertidal flats, these processes only took place during emersion in the light (Fig. 6b, c). As the tide comes in primary production stops, presumably due to sudden light extinction and physical disturbance of the sediment-inhabiting microalgae. The water is very turbid in the Oosterschelde estuary and water depths increase fast during flood-tide $(0.5 \mathrm{~m}$ within half an hour), so that no light reaches the sediment surface. As a whole, gross oxygen production rates measured during the emersion period with microelectrodes were of the same order of magnitude as those found in intertidal sediments with water-filled bell jars by Rugers van der Loeff et al. (1981), Van Es (1982), Rizzo \& Wetzel (1985) and Baillie (1986). However, De Jong et al. (unpubl.) showed that microalgae adapted to a permanent thin water layer exhibited similar chlorophyllbased production rates, but lower gross oxygen production rates, compared to air-exposed microalgae.

At the beginning and end of the emersion period, temporary changes in oxygen gradients were often noticed. Oxygen gradients were temporarily less steep and oxygen penetrated deeper into the sediment. When calculating oxygen fluxes we assumed a constant sediment diffusion coefficient. This resulted in dips in consumption rates (Fig. 6c). However, it is not likely that consumption rates change that fast. Probably the incoming or outgoing tide flushes the interstitial water, and hence changes the apparent sediment oxygen diffusion coefficient temporarily.

\section{Oxygen consumption relations}

The calculated $Q_{10}$ values for oxygen consumption agree well with literature values, ranging from 1.4 to 3.2 (Pamatmat 1971, Olanczuk-Neyman \& Vosjan 1977.
Hopkinson 1985, Andersen \& Helder 1987). However, these $Q_{10}$ values resulted from field measurements, and auto-correlations with other factors can play an important role (Hopkinson 1985).

Good correlations were found between oxygen consumption and maximum oxygen saturation, and between oxygen consumption and gross oxygen production. The maximum oxygen saturation is positively affected by both primary production and temperature. High oxygen saturation results in oxygen transport to deeper sediment layers. This results in more oxygenconsuming biomass and oxidation of reduced components in these layers, and hence in higher total oxygen consumption rates.

Dark oxygen influx of the Oosterschelde intertidal sediment $\left(0.6\right.$ to $\left.3.7 \mathrm{mmol} \mathrm{O}_{2} \mathrm{~m}^{-2} \mathrm{~h}^{-1}\right)$ is an order of magnitude higher than that found in deep-sea sediment $\left[0.02\right.$ to $0.15 \mathrm{mmol} \mathrm{m} \mathrm{m}^{-2} \mathrm{~h}^{-1}$ (Reimers \& Smith 1986. Grant \& Schwinghamer 1987. Silverberg et al. 1987)]. Hopkinson (1985) measured oxygen consumption rates of 1.6 to $4.4 \mathrm{mmol} \mathrm{m} \mathrm{m}^{-2} \mathrm{~h}^{-1}$ in his domes, placed on nearshore sediment without the presence of benthic primary production. Van Es (1982) found a dark community respiration on intertidal flats of 0.6 to $2.8 \mathrm{mmol} \mathrm{O}_{2} \mathrm{~m}^{-2} \mathrm{~h}^{-1}$ in water-filled bell jars. Our higher oxygen consumption rates during primary production agree well with those measured by Rizzo \& Wetzel (1985) (3.1 to $4.3 \mathrm{mmol} \mathrm{O} \mathrm{m}^{-2} \mathrm{~h}^{-1}$ ) and by Baillie (1986) ( 3.5 to $18.7 \mathrm{mmol} \mathrm{m}^{-2} \mathrm{~h}^{-1}$ ) on intertidal flats in the presence of microalgal oxygen production. Rizzo \& Wetzel (1985) also show production-enhanced oxygen consumption rates on a sandflat and a mudflat (cf. their Figs. $2 \& 3$ ). For phytoplankton, respiration is assumed to be proportional to the maximum photosynthetic rate. According to literature cited by Parsons et al. (1977), the total respiration rate for phytoplankton is ca $10 \%$ of primary production. Our higher values (dark oxygen consumption increased by 12 to $14 \%$ of gross oxygen production) can be explained by the fact that microelectrode measurements include all chemical and biological oxygen-consuming processes. For different stations in the Ems-Dollard Estuary, Van Es (1982) found a dark oxygen consumption rate of $1.3 \mathrm{mmol} \mathrm{O}_{2}$ $\mathrm{m}^{-2} \mathrm{~h}^{-1}$ and a production-enhanced consumption rate of $38 \%$. This high factor can be the result of an underestimation of the primary production (measured in well-mixed water-filled bell jars), higher oxygen consumption rates which included macrofaunal respiration, and/or a stirring effect. The above-mentioned production-enhanced consumption rates all fall within the range given by Langdon (1988) for phytoplankton (12 to $40 \%$ )

In the presence of benthic primary producers, up to between 60 and $70 \%$ of the oxygen produced is consumed immediately within the sediment. This 
phenomenon is described by Kuenen et al. (1986) for artificial filter biofilms. High oxygen consumption rates and production-enhanced oxygen consumption rates in artificial diatom biofilms were found by Jensen \& Revsbech (1989) as well. However, we were able to measure these processes in natural benthic diatom mats very accurately with the microelectrode oxygen gradient/production method. This method permits very precise calculation of oxygen budgets. Annual oxygen budgets for the Oosterschelde intertidal sediments will be published elsewhere (S. A. De Jong \& P. A. G. Hofman unpubl. data).

The sheltered stations ( 2 and 5) showed the highest oxygen production and oxygen consumption rates (Fig. 8), which may be due to a higher organic carbon content. Nevertheless, on a $24 \mathrm{~h}$ basis oxygen consumption equals or exceeds primary production, and no oxygen is left for non-sediment-inhabiting organisms. A net oxygen outflux to the water column over a $24 \mathrm{~h}$ period can only be achieved at high microphytobenthos biomass (visible diatom mats) and high light intensities.

Acknowledgements. This study was part of the BALANSproject granted by Rijkswaterstaat, Tidal Waters Division. We thank Dr W. Admiraal, Prof. Dr M. Donze, Dr W Helder, Dr P. Herman, Dr H. Lindeboom, Prof. Dr P. H. Nienhuis, and Dr H. M. Scholten for their critical remarks and fruitful discussions. The crew of the 'Luctor', W. J. L. Röber, J. A. van Sprundel and P. de Koeyer, are thanked for their hospitality and professional help. We are grateful for the assistance of $\mathrm{A}$. A. Bolsius in preparing the figures for this paper.

\section{LITERATURE CITED}

Andersen, F. Ø., Helder, W. (1987). Comparison of oxygen microgradients, oxygen flux rates and electron transport system activity in coastal marine sediments. Mar. Ecol. Prog. Ser. 37: 259-264

Anderson, L. G., Hall, P. O. J., Iverfeldt, $\AA$., Rutgers van der Loeff, M. M., Sundby, B., Westerlund, S. F. G. (1986). Benthic respiration measured by total carbonate production. Limnol. Oceanogr 31. 319-329

Baillie, P. W. (1986). Oxygenation of intertidal estuarine sediments by benthic microalgal photosynthesis. Estuar. coast. Shelf Sci. 22: 143-159

Berner, R. A. (1980). Early diagenesis. Princeton University Press, Princeton, New Jersey

Bointon, W. R., Kemp, W. M., Osborne, C. G., Kaumeyer, K. R., Jenkins, M. C. (1981). Influence of water circulation rate on in situ measurements of benthic community respiration. Mar. Biol. 65: 185-190

Booy, K., Helder, W., Sundby, B. (in press). Rapid redistribution of oxygen in a sandy sediment induced by changes in flow velocity of the overlying water. Neth. J. Sea Res.

Broecker, W. S., Peng, T. H. (1974). Gas exchange rate between sea and air. Tellus 26: 21-35

Bryan, J. R., Riley, J. P., Williams, P. J. LeB. (1976). A Winkler procedure for making precise measurements of oxygen concentrations for productivity and related studies. J. exp. mar. Biol. Ecol. 21. 191-197
Grant, J. (1986). Sensitivity of benthic community respiration and primary production to changes in temperature and light. Mar. Biol. 90: 299-306

Grant, J., Schwinghamer, P. (1987). Size partitioning of microbial and meiobenthic biomass and respiration on Brown's Bank, South-West Nova Scotia. Estuar. coast. Shelf Sci. 25: $647-661$

Helder, W., Anderson, F. Ø. (1987). An experimental approach to quantify biologically mediated dissolved silicate transport at the sediment-water interface. Mar Ecol. Prog. Ser 39: $305-311$

Hopkinson Jr, C. S. (1985). Shallow-water benthic and pelagic metabolism: evidence of heterotrophy in the nearshore Georgia Bight. Mar. Biol. 87: 19-32

Jensen, J., Revsbech, N. P. (1989). Photosynthesis and respiration of a diatom biofilm cultured in a new gradient growth chamber. FEMS Microbiol. Ecol. 62: 29-38

Jørgensen, B. B., Revsbech, N. P. (1985). Diffusive boundary layers and the oxygen uptake of sediments and detritus. Limnol. Oceanogr. 30: 111-122

Krantzberg, G. (1985). The influence of bioturbation on physical, chemical and biological parameters in aquatic environments: a review. Envir. Pollut. 39: 99-122

Kuenen, J. G., Jørgensen, B. B., Revsbech, N. P. (1986). Oxygen microprofiles of trickling filter biofilms. Wat. Res. 20: $1589-1599$

Langdon, C. (1988). On the causes of interspecific differences in the growth-irradiance relationship for phytoplankton. II. A general review. J. Plankton Res. 10: 1291-1312

Lindeboom, H. J., Sandee, A. J. J. De Klerk v. d. Driessche, H. A. J. (1985). A new bell jar/microelectrode method to measure changing oxygen fluxes in illuminated sediments with a microalgal cover. Limnol. Oceanogr. 30: 693-698

Liss, P. S. (1973). Process of gas exchange across an air-water interface. Deep Sea Res. 20: 221-238

Meyers, M. B., Fossing, H., Powell, E. N. (1987). Microdistribution of intestitial meiofauna, oxygen and sulfide gradients, and the tubes of macrofauna Mar. Ecol. Prog. Ser. 35: $223-241$

Olanczuk-Neyman, K. M., Vosjan, J. H. (1977). Measuring respiratory electron-transport-system activity in marine sediment. Neth. J. Sea Res. 11: 1-13

Pamatmat, M. M. (1971). Oxygen consumption by the seabed. IV Shipboard and laboratory experiments. Limnol. Oceanogr 16: $536-550$

Parsons, T R., Takahashi, M., Hargrave, B. (1977). Biological oceanographic processes. Pergamon Press, Oxford

Reimers, C. E. (1987). An in situ microprofiling instrument for measuring interfacial pore water gradients: methods and oxygen profiles from the North Pacific Ocean. Deep Sea Res. 34: 2019-2037

Reimers, C. E., Kalhorn, S., Emerson, S. R., Nealson, K. H. (1984). Oxygen consumption rates in pelagic sediments from the Central Pacific: first estimates from microelectrode profiles. Geochim. cosmochim. Acta 48: 903-910

Reimers, C. E., Smith, K. L. Jr (1986). Reconciling measured and predited fluxes of oxygen across the deep sea sediment-water interface. Limnol. Oceanogr 31: 305-318

Revsbech, N. P., Jørgensen, B. B. (1983). Photosynthesis of benthic microflora measured with high spatial resolution by the oxygen microprofile method: capabilities and limitations of the method. Limnol. Oceanogr. 28: 749-756

Revsbech, N. P., Jørgensen, B. B., Blackburn, T H., Cohen, Y. (1983). Microelectrode studies of the photosynthesis and $\mathrm{O}_{2}, \mathrm{H}_{2} \mathrm{~S}$ and $\mathrm{pH}$ profiles of a microbial mat. Limnol. Oceanogr. 28: 1062-1074

Revsbech, N. P., Sørensen, J., Blackburn, T H., Lomholt, J. P. 
(1980). Distribution of oxygen in marine sediments measured with microelectrodes. Limnol. Oceanogr. 25: 403-411

Rizzo, W. M., Wetzel, R. L. (1985). Intertidal and shoal benthic community metabolism in a temperate estuary: studies of spatial and temporal scales of variability. Estuaries 8: 342-351

Rutgers van der Loeff, M. M., Anderson, L. G., Hall, P. O. J., Iverfeldt, A., Josefson, A. B., Sundby, B., Westerlund, S. F. G. (1984). The asphyxiation technique: an approach to distinguishing between molecular diffusion and biologically mediated transport at the sediment-water interface. Limnol. Oceanogr. 29: 675-686

This article was submitted to the editor
Rutgers van der Loeff, M. M., Van Es, F. B., Helder, W., De Vries, R. T. P. (1981). Sediment water exchanges of nutrients and oxygen on tidal flats in the Ems-Dollard Estuary. Neth J. Sea Res. 15: 113-129

Silverberg, N., Bakker, J., Edenborn, H. M., Sundby, B. (1987). Oxygen profiles and organic carbon fluxes in Laurentian Trough sediments. Neth. J. Sea Res. 21: 95-105

Ullman, W. J., Aller, R. C. (1982). Diffusion coefficients in nearshore marine sediments. Limnol. Oceanogr. 27 : 552-556

Van Es, F. B. (1982). Community metabolism of intertidal flats in the Ems-Dollard Estuary. Mar Biol. 66: 95-108

Manuscript first received: June 14, 1989

Revised version accepted: November 2, 1990 